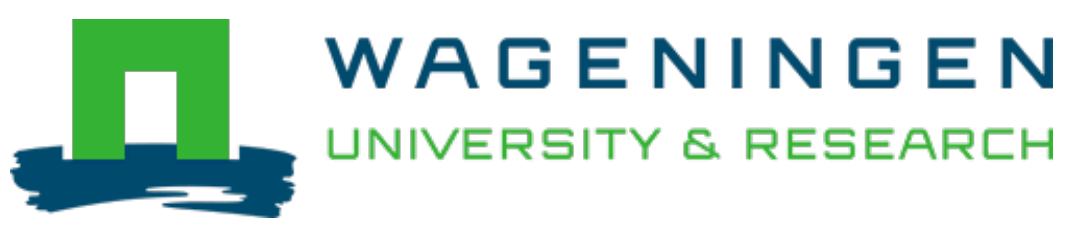

\title{
Quality perceptions of stakeholders in Beninese export-oriented shrimp chain
}

Journal of Food Protection

Dabade, D.S.; Besten, H.M.W.; Azokpota, P.; Nout, M.J.R.; Hounhouigan, D.J. et al https://doi.org/10.4315/0362-028X.JFP-13-525

This publication is made publicly available in the institutional repository of Wageningen University and Research, under the terms of article $25 \mathrm{fa}$ of the Dutch Copyright Act, also known as the Amendment Taverne. This has been done with explicit consent by the author.

Article $25 \mathrm{fa}$ states that the author of a short scientific work funded either wholly or partially by Dutch public funds is entitled to make that work publicly available for no consideration following a reasonable period of time after the work was first published, provided that clear reference is made to the source of the first publication of the work.

This publication is distributed under The Association of Universities in the Netherlands (VSNU) 'Article $25 \mathrm{fa}$ implementation' project. In this project research outputs of researchers employed by Dutch Universities that comply with the legal requirements of Article $25 \mathrm{fa}$ of the Dutch Copyright Act are distributed online and free of cost or other barriers in institutional repositories. Research outputs are distributed six months after their first online publication in the original published version and with proper attribution to the source of the original publication.

You are permitted to download and use the publication for personal purposes. All rights remain with the author(s) and / or copyright owner(s) of this work. Any use of the publication or parts of it other than authorised under article $25 \mathrm{fa}$ of the Dutch Copyright act is prohibited. Wageningen University \& Research and the author(s) of this publication shall not be held responsible or liable for any damages resulting from your (re)use of this publication.

For questions regarding the public availability of this publication please contact openscience.library@,wur.nl 


\title{
Research Note
}

\section{Quality Perceptions of Stakeholders in Beninese Export-Oriented Shrimp Chain}

\author{
D. SYLVAIN DABADE, ${ }^{1,2}$ HEIDY M. W. DEN BESTEN, ${ }^{2 *}$ PAULIN AZOKPOTA, ${ }^{1}$ M. J. ROB NOUT, ${ }^{2}$ \\ D. JOSEPH HOUNHOUIGAN, ${ }^{1}$ AND MARCEL H. ZWIETERING ${ }^{2}$ \\ ${ }^{1}$ Faculty of Agronomic Sciences, University of Abomey-Calavi, 01 B.P. 526 Cotonou, Benin; and ${ }^{2}$ Laboratory of Food Microbiology, \\ Wageningen University, P.O. Box 17, 6700 AA Wageningen, The Netherlands
}

MS 13-525: Received 6 December 2013/Accepted 20 April 2014

\begin{abstract}
In recent years, the Beninese shrimp sector has faced a ban on export to the European Union due to lack of compliance with food safety standards. The present study aimed at obtaining insight into the factors that determine shrimp quality and safety in Benin. A survey was conducted to investigate the relationships between stakeholders, the conditions under which shrimps are handled at fishing areas and processed at shrimp plants, and the stakeholders' perceptions of quality. A total of 325 fishermen, 128 intermediate traders, 12 collectors, and 3 shrimp processing plant managers were interviewed face to face. The results showed that various specific relations existed between the stakeholders. For example, loyalty was ensured by family relationships, or incentives were provided to ensure a supply of shrimps between stakeholders. Shrimp handling practices during the steps prior to shrimp processing at the plants were not in agreement with the requirements of the European regulations. For example, shrimps were kept at ambient temperature $\left(28 \pm 1^{\circ} \mathrm{C}\right)$ by $94.1 \%$ of fishermen and $60.9 \%$ of intermediate traders. Shrimps were also stored in inappropriate holding containers and washed with nonpotable water. Fishermen, intermediate traders, and collectors considered shrimp size and texture their priority quality attributes, whereas plant managers considered shrimp appearance (freshness) and texture their priority quality attributes. This survey demonstrated that the steps prior to shrimp processing at the plants are the critical steps for shrimp quality and safety because of temperature abuse and inappropriate hygienic conditions. There is a need to communicate and provide incentives for the stakeholders in the first part of the chain to give priority to shrimp freshness. Moreover, training in Good Fishing Practices and safe food handling practices and evaluation of compliance with the practices through monitoring will contribute to better shrimp quality and safety management.
\end{abstract}

In recent years, food safety standards have become an increasingly prominent issue for global trade in agricultural and food products (16). Consumers and authorities have become more aware of food safety risks and expect safe handling of food $(5,17,28)$. To ensure that imports of fishery products into the European Union can take place, the Food and Veterinary Office (FVO) of the European Commission has sent missions to all exporting countries to assess the hygienic conditions under which fishery products intended for export to the European Union were produced. In 2002, the FVO experts found that, in Benin, the shrimp collection network from the landing sites to the processing plants was not well organized and that the hazard analysis and critical control point plans at the plants were not well documented. In addition, Benin lacked the legal basis to ensure shrimp quality and safety (12). In reaction to the results of the FVO technical inspection, the national government decided to self-ban shrimp export as a precautionary action. Shrimps were one of the most

\footnotetext{
* Author for correspondence. Tel: 31-317-483213; Fax: 31-317-484978; E-mail: Heidy.denBesten@wur.nl.
}

exported products from Benin, generating jobs and revenues; the ban resulted in 60,000 lost jobs and about 10 million Euros in lost revenues from 2003 to 2006 (19). The ban was lifted in 2005. However, during their second visit in 2009, the FVO experts observed that only the Beninese legislation could be considered equivalent to the European Union feed and food law; the deficiencies related to shrimp quality management remained.

An important strategy for developing countries to reduce poverty is to take advantage of international trade (18). Therefore, Benin should develop and promote quality improvement spanning the entire supply chain to meet customers' expectations. The food chain may consist of several independent economic stakeholders, but the success of the final product depends on the concerted efforts of all stakeholders throughout the chain (23). Therefore, the aim of the present work was to obtain insight into the factors determining shrimp quality and safety in Benin by exploring the entire supply chain. Such an investigation is necessary to reveal the shortcomings related to shrimp quality and safety in Benin. The objectives of the present work were (i) to investigate the structure of the Beninese export-oriented shrimp chain and the relationships between stakeholders, 


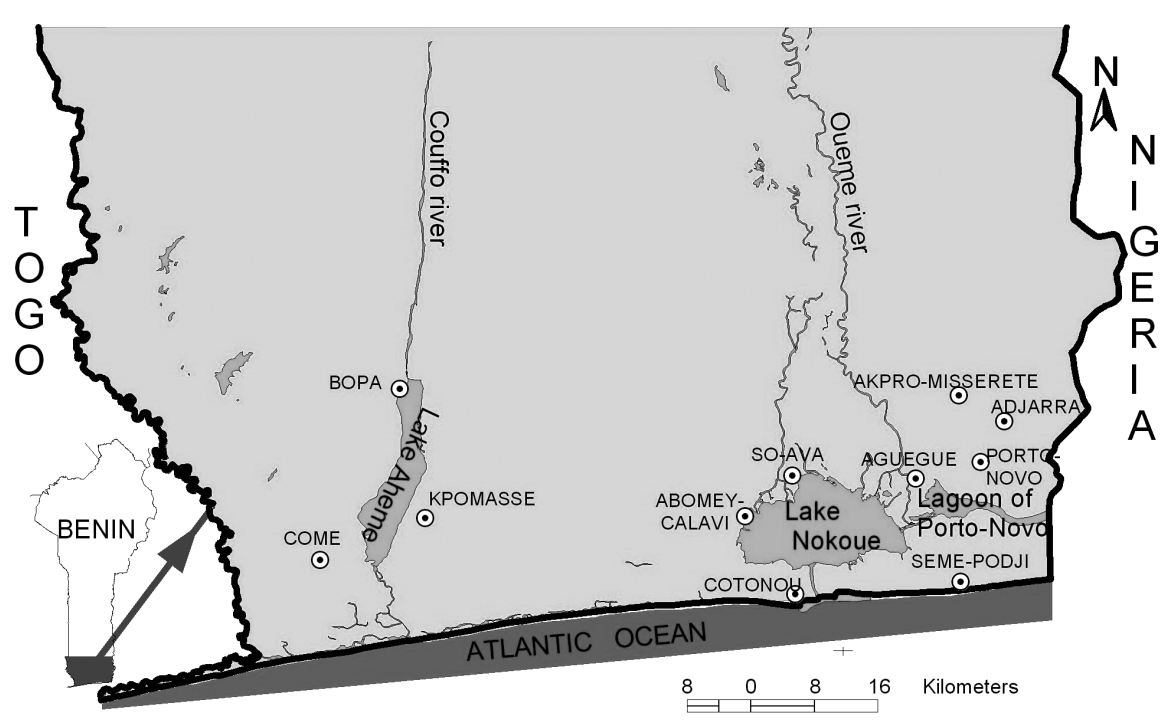

FIGURE 1. Map of Benin showing the fishing areas and the capitals of the municipalities included in the study (adapted with permission from the Beninese National Geographic Institute, 1992). $\odot$, capital of municipality. (ii) to determine the conditions under which shrimps are handled at fishing areas and processed at shrimp plants, and (iii) to determine stakeholders' perceptions of quality.

\section{MATERIALS AND METHODS}

Sampling of informants. The survey was conducted in the municipalities located around Lakes Nokoue and Aheme and the lagoon of Porto-Novo (Fig. 1), which are the main shrimp fishing areas in Benin. Shrimp freezing plant managers and three other groups of stakeholders, namely, fishermen, intermediate traders, and collectors, who are involved in shrimp transport to plants, were surveyed. To compute the sample size $n$ of each group of stakeholders to be interviewed, the following formula was used (9):

$$
n=\frac{4 p(1-p)}{d^{2}}
$$

where $n$ is the total number of stakeholders in the group of concern to be interviewed, $d$ is the expected margin of error in the conclusion, which was fixed at 0.05 , and $p$ is the proportion of the group of stakeholders of concern among the total number of fishery stakeholders (the fishery community comprised shrimp fishers, other fishermen, fishery product traders, and fishery product processors) living in the area studied, which could be derived from the results of the census on fisheries carried out in Benin in 2006. For instance, the total number of fishery stakeholders (fishery community) living in the area studied was 29,559. Among them, 8,485 were shrimp fishers, 2,586 were shrimp intermediate traders, and 150 were shrimp collectors. A total of 328 fishermen, 128 intermediate traders, 12 collectors (instead of 9 generated by the formula), and the managers of all three Beninese freezing plants were interviewed. The numbers of fishermen, intermediate traders, and collectors interviewed in each municipality were proportional to its number of fishery stakeholders and were calculated as follows:

$$
n_{i}=n \cdot k_{i}
$$

where $n_{i}$ is the number of stakeholders in the group of concern to be interviewed in the municipality, $n$ is the total number of stakeholders in the group of concern to be interviewed for the study (for example, $n=328$ in the case of fishermen), and $k_{i}$ is the proportion of the number of stakeholders in the group of concern of a municipality $i$ among the total number of stakeholders in the group of concern living in the area studied.
Questionnaire design and field data collection. Questionnaires were formulated for each group of stakeholders. The questionnaires were divided into four main parts. The first part dealt with demographic characteristics of the interviewee (name, age, gender, level of education, and contact details). The second part was related to the stakeholder's shrimp handling practices. The third part investigated the interviewee's shrimp quality perceptions, and the fourth part focused on the relationship between the interviewee and his/her buyer, i.e. the next stakeholder along the chain. Questionnaires for freezing plant managers also included questions related to shrimp processing steps. The questionnaires consisted mostly of multiple-choice questions which included the answer choice "other." The answer choice "other" was further specified by the respondents. The questionnaires were administered by three interviewers using face-to-face interviews. The interviewers were agronomic engineers experienced in conducting surveys in rural areas. A training workshop was organized to get the interviewers familiarized with the objectives of the study, the content of the questionnaires, and the appropriate way to meet the respondents. The questionnaires were first tested in a pilot survey that included 17 fishermen, 7 intermediate traders, 2 collectors, and 1 shrimp freezing plant manager. Then, the questionnaires were adjusted when needed and used for the formal survey.

Data were collected in the villages of selected municipalities from February to April 2011. In each village, interviews with randomly selected informants were conducted in their local language. The response rates were $99.1 \%$ for fishermen $(n=$ $325)$ and $100 \%$ for intermediate traders $(n=128)$, collectors $(n=$ $12)$, and shrimp plant managers $(n=3)$.

Data analysis. Raw data were recorded in Microsoft Excel, and descriptive statistics were calculated. Data related to fishing duration and shrimp storage periods by the fishermen and the intermediate traders were subjected to analysis of variance using SAS version 9.2, followed by a Tukey's multiple comparison test. Significance was accepted at a $P$ value of $<0.05$.

\section{RESULTS}

The structure of the Beninese export-oriented shrimp chain. The sociodemographic profiles of the respondents are presented in Table 1. All shrimp fisher respondents were male, while almost all intermediate traders (97.7\%) were female. Most of the respondents were 
TABLE 1. Sociodemographic profiles of the respondents

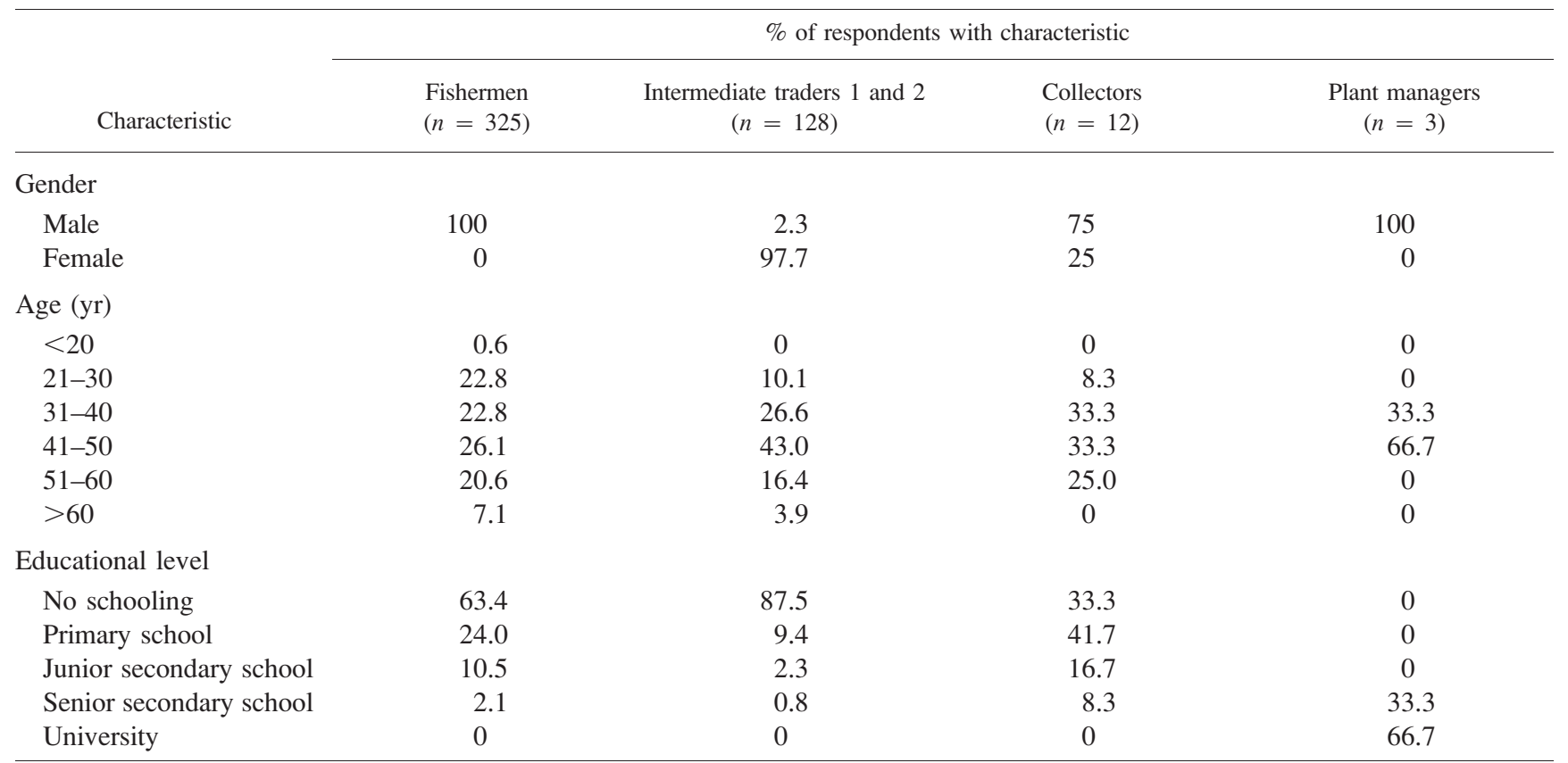

between 41 and 50 years old. Most of the shrimp fishers and intermediate traders did not receive any formal education, while shrimp plant managers had at least secondary school level.

Diverse relationships exist among stakeholders involved in the Beninese shrimp chain (Fig. 2). After fishing, some fishermen (33\% of respondents) sell shrimps to their wives, the intermediate traders 1 . Most of these women (77\% of respondents) sell their product to women or men specializing in shrimp precollection, the intermediate traders

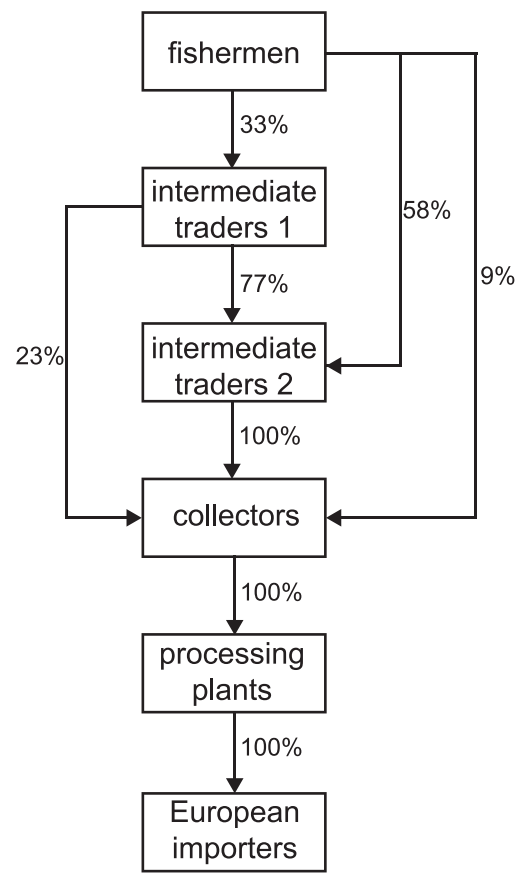

FIGURE 2. The export-oriented shrimp chain in Benin. The percentages indicate the proportions of stakeholders using the specified routes.
2, who also buy shrimps directly from $58 \%$ of the fishermen interviewed. The difference between the intermediate traders 1 and intermediate traders 2 is that the former buy shrimps only from their husbands, while the latter buy their products from various fishermen and intermediate traders 1 . Special relations may exist between the fishermen and the intermediate traders 2 . For instance, intermediate traders 2 provide fishing tackle and loans in advance to $15 \%$ and $11 \%$ of fishermen, respectively. Some fishermen $(5 \%$ of respondents) sell their products to intermediate traders 2 solely because of a family relationship. In addition to these types of relationships, the intermediate traders 2 give food and drink to fishermen selling them shrimps in order to ensure their loyalty. The intermediate traders 2 in turn sell shrimps to the collectors, who can also be supplied directly by the fishermen or their wives (intermediate traders 1). However, there is a conflict of interest between the fishermen or their wives and intermediate traders 2, who believe that all the shrimps should be channeled through them to collectors. Thirty-two percent of intermediate traders 1 and 2 asserted having particular relations with the collectors, who either motivate them in the beginning of the shrimp season by organizing a party or give them some money in advance. The collectors transport shrimps directly to the plants, where they are processed and exported to Europe. In order to gain the confidence of collectors, the plants' owners take various incentive measures. For example, the plant can put its means of transport at the collectors' disposal and can reward the best suppliers at the end of the shrimp season.

Shrimp handling and processing. Shrimp fishing in Benin is an activity held by the communities settled on or near water bodies, which pass it on from generation to generation. More than $97 \%$ of the fishermen interviewed confirmed having learned shrimp fishing from their 
TABLE 2. Fishing nets, shrimp holding containers, and storage methods used by fishermen

\begin{tabular}{|c|c|c|}
\hline Fishing condition & Variant & $\begin{array}{l}\% \text { of informants } \\
\text { using the variant }{ }^{a}\end{array}$ \\
\hline \multirow{6}{*}{ Fishing net } & Drift net & 49.2 \\
\hline & Medokpokonou $^{b}$ & 25.2 \\
\hline & Gill net & 12.0 \\
\hline & Bow net & 9.8 \\
\hline & Gbagbaloulou $^{c}$ & 1.9 \\
\hline & Cast net & 1.9 \\
\hline \multirow[t]{5}{*}{ Holding container } & Boat & 62.5 \\
\hline & Plastic basket & 20.6 \\
\hline & Wooden basket & 13.8 \\
\hline & Polystyrene bags & 2.2 \\
\hline & Cool box & 0.9 \\
\hline \multirow[t]{3}{*}{ Storage method } & Ambient temp $\left(28^{\circ} \mathrm{C}\right)$ & 94.1 \\
\hline & Ice & 3.4 \\
\hline & $\begin{array}{l}\text { Lake/lagoon water } \\
\quad\left(23.5^{\circ} \mathrm{C}\right)\end{array}$ & 2.5 \\
\hline
\end{tabular}

${ }^{a}$ The total number of fishermen was 325 .

${ }^{b}$ Medokpokonou means literally "'only one person laughs.' It is the name given to a net with fine mesh capable of capturing even the small shrimps and other fishery products.

${ }^{c}$ Gbagbaloulou is also a local name, given to a tapered net with fine mesh.

relatives. Fishing generally takes place at night or early in the morning (4:00 to 6:00 a.m.). The fishing season varies, but it generally runs from December to September. Table 2 shows the fishing nets, shrimp holding containers, and storage methods used by the fishermen. The most widely used net is the drift net. However, fishing nets with fine meshes $(<20 \mathrm{~mm})$ called Medokpokonou and Gbagbaloulou, which were prohibited (2), are still used in Lake Nokoue and Lake Aheme, respectively. The captured shrimps are often poured directly into a wooden boat ( $62.5 \%$ of respondents). Refrigerated storage of shrimps by the fishermen is not a common practice in Benin. Only $3.4 \%$ of the interviewed fishermen store their shrimps on ice. The shrimps are stored at ambient temperature (28 \pm $1{ }^{\circ} \mathrm{C}$ ) by most of the fishermen ( $94.1 \%$ of respondents) or, sometimes, kept in a plastic basket containing the lake or lagoon water, with an average temperature of $23.5 \pm 0.5^{\circ} \mathrm{C}$ (2.5\% of respondents). There is a significant difference $(P$ $<0.05$ ) between the average fishing duration with the various types of fishing nets. The fishing duration of fishermen using drift nets was $5.6 \pm 1.3 \mathrm{~h}(n=160)$. This time was approximately two times higher than the time spent by the fishermen who use bow nets $(n=32)$, Medokpokonou $(n=82)$, or cast nets $(n=6)$. The fishing durations using gill nets and Gbagbaloulou are $3.6 \pm 0.9 \mathrm{~h}(n$ $=39)$ and $3.2 \pm 1.2 \mathrm{~h}(n=6)$, respectively. During shrimp fishing with drift nets, 3 or 4 successive captures are realized and poured into the same container. About $4 \mathrm{~h}$ elapse between the first capture and the last one. After fishing, fishermen who use ice keep the shrimps for $4.1 \pm 3.7 \mathrm{~h}(n=11)$. This holding time is significantly longer $(P<0.05)$ than the holding time by fishermen who store shrimps in lake or lagoon water $(1.4 \pm 1.2 \mathrm{~h})(n=8)$ or at ambient temperature
$(1.4 \pm 0.6 \mathrm{~h})(n=306)$. The holding time between the end of fishing and delivery allows fishermen to get in touch with their customers and, also, to separate shrimps from other aquatic species captured.

Shrimp precollection is conducted by intermediate traders 1 and 2 who receive shrimps at home or on shore. Baskets are the materials most used for the precollection (61.7\% of the respondents). During the precollection, shrimps are stored on ice by $25 \%$ of the intermediate traders. Most of the intermediate traders $(60.9 \%)$ just wash the shrimps using water from the lake, lagoon, well, or pump and keep their products at ambient temperature $(28 \pm$ $1^{\circ} \mathrm{C}$ ) in the holding container until their delivery. The remainder $(14.1 \%)$ store washed shrimps in water $(23.5 \pm$ $0.5^{\circ} \mathrm{C}$ ) until the time of sale. The shrimp holding time by intermediate traders who store shrimps at ambient temperature is $1.5 \pm 0.8 \mathrm{~h}(n=78)$. This holding time is significantly shorter $(P<0.05)$ than the holding time by intermediate traders who store shrimps in ice $(3.1 \pm 2.0 \mathrm{~h})$ $(n=32)$ or in lake or lagoon water $(2.9 \pm 1.7 \mathrm{~h})(n=18)$.

Like shrimp precollection, shrimp collection takes place in an open environment where intermediate traders and some fishermen deliver their products to collectors. All the collectors use iceboxes in which they store collected shrimps on ice. The ice used is generally provided by shrimp processing plants. However, collectors are sometimes supplied with ice at the local market. The water used to make ice is from tap water and meets the standards mentioned in decree no. 2001-094 (3). After the collection, which lasts on average $4.7 \pm 1.9 \mathrm{~h}(n=12)$, shrimps are transported by taxi. In the villages with difficult access, part of the transport of shrimps is carried out on motorcycle or by boat. The final destination of shrimps is one of the three shrimp processing plants in Cotonou (economic capital of Benin). The average duration of the transport is $2.1 \pm 1.2 \mathrm{~h}$ $(n=12)$.

Upon receipt of the shrimps, the processors carry out a sensory examination based on the color, consistency, smell, and presence of foreign bodies, including sticks and meshes. The temperature in the center of the mass of shrimps is then measured using a probe thermometer. This temperature should be lower than $7{ }^{\circ} \mathrm{C}$ according to the plant managers interviewed. However, when the temperature is between 7 and $10^{\circ} \mathrm{C}$, the shrimps are accepted but with a rapid lowering of temperature by the addition of ice. Shrimps are rejected when the temperature is higher than $10^{\circ} \mathrm{C}$. The rejected shrimps are smoked or fried and sold in Benin and in the subregion, mainly in Nigeria, according to the plant managers interviewed. Sometimes shrimps of large size without any physical damage and showing no sign of spoilage are just washed, kept on ice, and exported to European countries, namely, Belgium, France, and Spain. However, shrimps are often subjected to different processing steps (Fig. 3) prior to export. Received shrimps are weighed and washed with tap water at a temperature of about $5^{\circ} \mathrm{C}$ to get rid of sand and foreign bodies. Shrimps are washed a second time in water of about $5^{\circ} \mathrm{C}$ containing active chlorine at 0.2 to $0.5 \mathrm{ppm}$ for $1 \mathrm{~min}$ to kill some microorganisms. Afterwards, they are soaked in a solution 


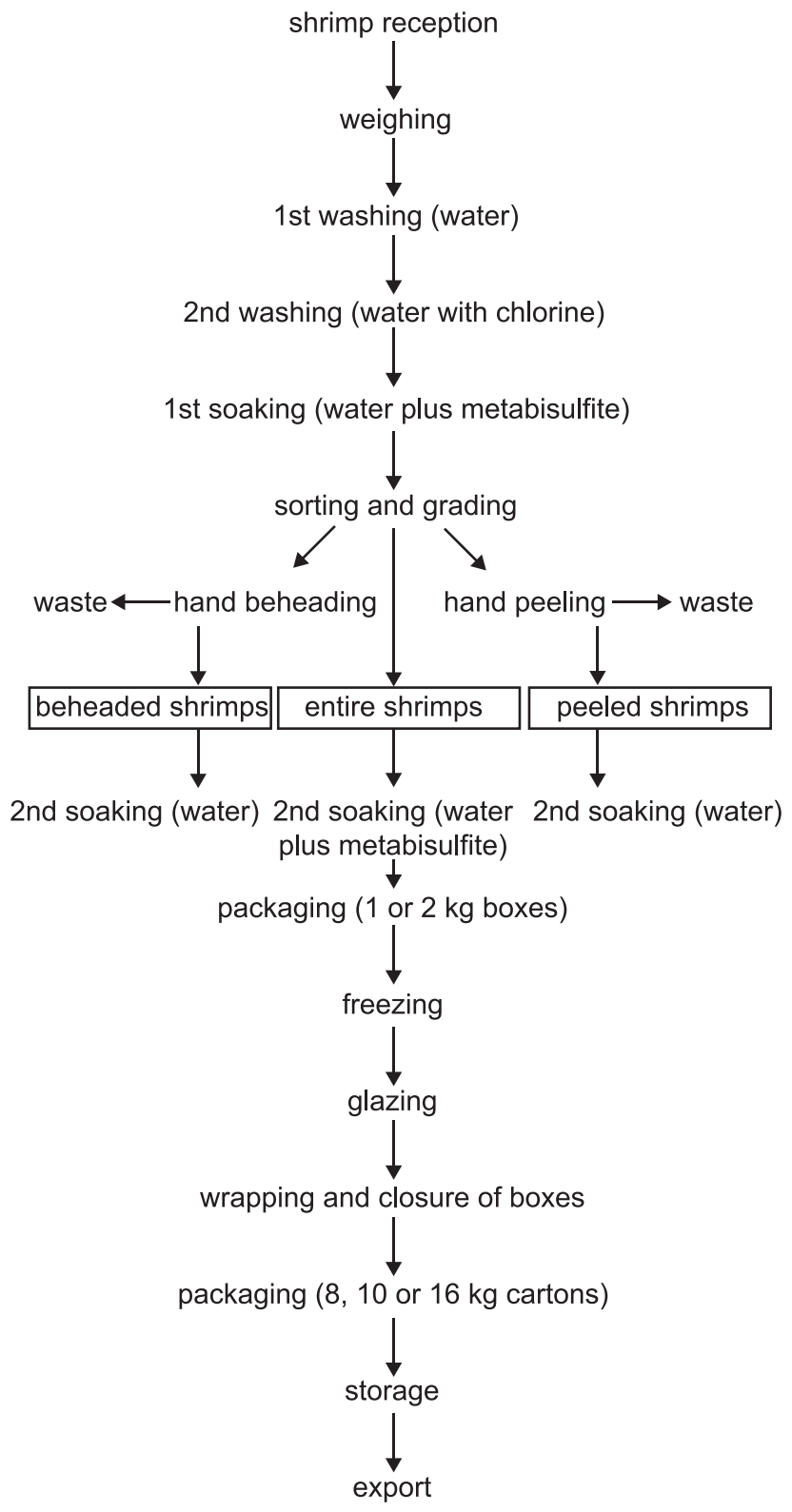

FIGURE 3. Flow chart of plant-level shrimp processing for exportation purposes.

of $1 \%$ metabisulfite for 1 to $3 \mathrm{~min}$ at about $5^{\circ} \mathrm{C}$ to prevent the development of melanosis (blackspot). Shrimps are then sorted, graded, and distributed into three processing lines: beheaded shrimps, peeled shrimps, and entire shrimps. The entire shrimps undergo a second soaking in a solution of $0.25 \%$ metabisulfite for 1 to $2 \mathrm{~min}$ at about $5^{\circ} \mathrm{C}$, whereas the beheaded and peeled shrimps are soaked in simple water for $3 \mathrm{~min}$ at about $5^{\circ} \mathrm{C}$. The shrimps are then packed in boxes of 1 or $2 \mathrm{~kg}$, frozen at $-40^{\circ} \mathrm{C}$, and glazed at about $5^{\circ} \mathrm{C}$. To protect the shrimps, they are wrapped using sterile shrink films. The boxes are closed and packed in cartons of 8,10 , or $16 \mathrm{~kg}$. The cartons are stored in a freezing room (about $-20^{\circ} \mathrm{C}$ ) and then exported to Europe.

Stakeholders' quality perceptions. The different groups of stakeholders do not have the same perceptions of shrimp quality (Table 3). The majority of fishermen, intermediate traders 1 and 2, and collectors consider shrimp size and texture to be their first two priority quality attributes, whereas at the plant level, plant managers consider the appearance (freshness) and the texture of shrimps their first two priority quality attributes.

As far as quality criteria are concerned, all stakeholders prefer shrimps that are large (at least $15 \mathrm{~g}$ per piece of shrimp), firm, and without any physical damage (whole shrimps without injury). Shrimp freshness is evaluated based on the carapace, which should be shiny. Also, fresh shrimps should keep their natural (grey) color, especially in the head, where a red color is perceived as a sign of spoilage, and should not produce any off-odor. The decision on a batch of shrimps which does not meet the quality criteria depends on the stakeholder who wants to buy the product. The intermediate traders 2 accept the product but may reduce the price, the collectors sort out the shrimps that comply with their criteria and reject the remainder, and the processors reject the entire batch.

\section{DISCUSSION}

Shrimp chain structure. The structure of the shrimp chain in Benin shows that there are many specific relations between the stakeholders. According to Harland (13), relationships between stakeholders represent valuable bridges, as they give one stakeholder access to the resources of another. According to Trienekens et al. (27), the acceptance of a product by the stakeholders of a supply chain depends on a combination of price, quality and safety, and associated guarantees. However, in the Beninese shrimp supply chain, some stakeholders may accept the shrimps only on the basis of the relationships existing between stakeholders. For instance, some wives buy their husbands' shrimps at normal price whatever their quality because, according to the local custom, a woman should not oppose her husband. This asymmetric relationship, i.e. unbalanced power between stakeholders (29), may affect shrimp quality, as the

TABLE 3. Stakeholders' first two priority quality attributes

\begin{tabular}{lccccc}
\hline \multicolumn{1}{c}{ Stakeholders } & \multicolumn{5}{c}{ \% whose priority quality attributes are ${ }^{a}$ : } \\
\cline { 2 - 6 } & 1,2 & 1,3 & 1,4 & 2,1 & 2,3 \\
\hline Fishermen $(n=325)$ & 72.3 & 26.1 & 0 & 0.9 & 0.6 \\
Intermediate traders 1 and 2 $(n=128)$ & 68.0 & 22.6 & 7.8 & 1.6 & 0 \\
Collectors $(n=12)$ & 75.0 & 8.3 & 8.3 & 8.3 & 0 \\
Plant managers $(n=3)$ & 0 & 0 & 0 & 0 & 0 \\
\hline
\end{tabular}

\footnotetext{
${ }^{a}$ Quality attributes: 1, size; 2, texture; 3, color; 4, lack of physical damage; 5, appearance.
} 
fishermen may not be motivated to improve the quality of their products.

The intermediate traders 2 accept all the shrimps from the fishermen or the intermediate traders 1 because they smoke the shrimps of marginal quality, which they sell at the local and subregional markets. However, the quality of shrimps intended for export can also be affected, and shrimps will not meet the quality criteria stated in the inspection manual procedures of the Beninese fishery directorate (unpublished document). Deficiencies related to shrimp quality at this stage of the chain can affect the end product. In fact, the quality and safety of the end product in a food supply chain depend on the roles played by all members of the supply chain (27).

Shrimp handling. Many shortcomings related to shrimp quality were observed during the survey. The captured shrimps are often dumped into the wooden boats, where different catches are mixed. This practice does not meet the requirements of European Commission Regulation No 853/2004 (10), which states that each successive catch must be kept separated. Moreover, the cold chain is not well maintained. Shrimps are stored at ambient temperature $\left(28^{\circ} \mathrm{C}\right)$ during the fishing and the precollection before their delivery to the collectors, who finally put them on ice. This practice is in violation of the requirements of the Codex Alimentarius (7) and of European Commission Regulation No 853/2004 (10), which stipulate that chilling of fishery products should start as soon as possible. In fact, shrimps are extremely sensitive to deterioration (21). Unlike other crustaceans (e.g., crabs and lobsters), which can be kept alive until processing, shrimps die soon after being caught, and they are often contaminated with bacteria from their endogenous microflora, as well as from the mud trawled up with them (1). Therefore, the storage temperature is crucial $(8,20)$. For instance, as reported by Mendes et al. (21), sensory analysis of fresh samples showed that raw chilled shrimps reached the limit of acceptability (50\% rejection) after 4 days in ice, whereas $100 \%$ of the samples stored at room temperature $\left(22^{\circ} \mathrm{C}\right)$ were rejected after $24 \mathrm{~h}$.

In addition, the quality of lake and lagoon water used to wash shrimps is not in agreement with the requirements of European Commission Regulation No 853/2004 (10). This nonpotable water may be a source of contamination. In fact, the microbial status of seafood after catch is closely related to the environmental conditions and the microbiological quality of the water (11). Also, shrimp collection in an unprotected environment is in violation of the European Commission Regulation (10), which states that fishery products must be kept in a protected environment.

Our survey showed that, in Benin, shrimps are not handled properly and therefore may pose a potential risk to public health because improper handling practices may cause food contamination with pathogens and, consequently, foodborne disease $(15,24,26)$. Stakeholders involved in the Beninese shrimp sector should meet one of the key principles of the European regulations on the hygiene of foodstuffs (10), which stipulates that it is necessary to ensure food safety throughout the food chain, starting with the primary product. This is of great importance, given that food safety starts at primary production (14) and further processing can never restore the poor quality of shrimps improperly handled between the harvesting and the processing periods (4).

To ensure shrimp quality and safety, there is a need to train the fishermen in Good Fishing Practices and shrimp handlers in safe food handling practices. However, it is known that food hygiene training will only be effective if the resources and systems are in place to encourage food handlers to implement good practices $(6,25)$. Therefore, other measures, such as building adequate facilities for shrimp collection at the landing sites and providing incentives for fishermen and shrimp handlers to improve hygiene, are needed. In addition, the use of ice by upstream stakeholders (fishermen and intermediate traders) should be promoted.

Shrimp quality perception. The upstream stakeholders in the chain give priority to shrimp size because they can make more money with shrimps that weigh more. There is concordance between our results and the results of Omemu and Aderoju (22), who concluded from a survey conducted in Benin's neighboring country (Nigeria) that vendors considered the volume and the price more important than freshness and cleanliness when buying food to be cooked or vended. The fact that nonfresh shrimps can be smoked or fried and sold in Benin or in the subregion also explains why the upstream stakeholders do not give priority to shrimp freshness. The shrimp plant managers, on the other hand, give priority to shrimp freshness because they must ensure the quality of exported products. In fact, products exported to Europe are regularly inspected on the market or at the border, and noncompliant products are rejected. Therefore, there is a need to inform upstream stakeholders about the importance of shrimp freshness, and incentives may be developed to reach this goal.

In conclusion, this study shows that the conditions under which shrimps are handled in Benin are not in agreement with the requirements of European regulations. The steps prior to shrimp processing at the plants, namely fishing, precollection, and collection, are the critical steps for shrimp quality and safety in Benin because of temperature abuse and inappropriate hygienic conditions. To fulfill the requirements of European regulations, joint efforts should be made. Because of the importance of foreign currency to its economy, Benin should provide training in Good Fishing Practices and safe food handling practices and develop incentives to improve shrimp quality and safety. The compliance with good practices should also be evaluated through monitoring. Moreover, it is important to ensure that the relationship between stakeholders, for example, a family relationship, do not pose a threat to shrimp quality and safety. This is one of the challenging factors to be taken into account in the strategies to improve shrimp quality and safety. The importing countries might provide technical and managerial assistance for exporting countries with limited resources to implement food safety requirements. A ban on products from exporting countries 
will certainly protect the health of their European Union consumers but may also prevent these consumers from consuming some foods they have a particular interest in, for instance, because of their organoleptic qualities. Our study highlights how a chain-wide survey can reveal technical and social aspects of relevance for better management of food safety and quality along the chain. Also, it provides data on time and temperature regimes along the chain, which can be used to evaluate relevant scenarios to determine the growth of pathogenic organisms and spoilers in future studies.

\section{ACKNOWLEDGMENTS}

This study was funded by NUFFIC, The Netherlands Universities Foundation For International Cooperation, project NPT/BEN/263. The objective of the project was to strengthen the contribution of the institution of higher education to an improved control of the quality of the priority agricultural export of Benin.

\section{REFERENCES}

1. Adams, M. R., and M. O. Moss. 2000. Food Microbiology, 2nd ed. Royal Society of Chemistry, Cambridge, UK.

2. Anonymous. 1998. Décret portant interdiction des engins de pêche dénommés Medokpokonou, Dogbo et Wan dans les plans d'eau du territoire de la République du Bénin. Available at: http://faolex.fao. org/docs/pdf/ben17498.pdf. Accessed 20 June 2012.

3. Anonymous. 2001. Décret fixant les normes de qualité de l'eau potable en République du Bénin. Décret no. 2001-094 du 20 février 2001. Available at: http://bj.chm-cbd.net/implementation/lois/fol655809/ fol787758/decreteaup.pdf. Accessed 16 June 2012.

4. Antony, M. M., G. Jeyasekaran, R. J. Shakila, and S. A. Shanmugam. 2002. Microbiological quality of raw shrimps processed on seafood processing plants of Tuticorin, Tamil Nadu, India. Asian Fish. Sci. 15:33-41.

5. Beulens, A. J. M., D. F. Broens, P. Folstar, and G. J. Hofstede. 2005. Food safety and transparency in food chains and networks. Relationships and challenges. Food Control 16:481-486.

6. Clayton, D. A., C. J. Griffith, P. Price, and A. C. Peter. 2002. Food handlers' beliefs and self-reported practices. Int. J. Environ. Health Res. 12:25-39.

7. Codex Alimentarius Commission. 2012. Code of practice for fish and fishery products, 2nd ed. CAC/RCP 52-2003. World Health Organization, Food and Agriculture Organization of the United Nations, Rome. Available at: ftp://ftp.fao.org/codex/publications/ Booklets/Practice_code_fish/CCFFP_2012_EN.pdf.

8. Cyprian, O. O., K. Sveinsdottir, H. Magnusson, and E. Martinsdottir. 2008. Application of quality index method (QIM) scheme and effects of short-time temperature abuse in shelf-life study of fresh water arctic char (Salvelinus alpinus). J. Aquat. Food Prod. Technol. 17: 303-321.

9. Dagnelie, P. 1998. Statistiques théoriques et appliquées. Inférence statistique à une et à deux dimensions Tome 2. De Boeck et Larcier, Brussels.

10. European Commission. 2004. Commission Regulation (EC) No 853/ 2004 of the European Parliament and of the Council of 29 April 2004 laying down specific hygiene rules for food of animal origin. Off. $J$. Eur. Union L 139:55-205.
11. Feldhusen, F. 2000. The role of seafood in bacterial foodborne diseases. Microb. Infect. 2:1651-1660.

12. Food and Veterinary Office. 2003. Rapport concernant une mission en République du Bénin du 7 au 11 octobre 2002 concernant les conditions de production et d'exportation vers l'Union Européenne des produits de la pêche. DG (Sanco)/8719/2002—R Final. Available at: http://ec.europa.eu/food/fvo/rep_details_en.cfm?rep_id=888. Accessed 16 May 2012.

13. Harland, C. M. 1996. Supply chain management: relationships, chains and networks. Brit. J. Manag. 7:S63-S80.

14. Havelaar, A. H., S. Brul, A. de Jong, R. de Jonge, M. H. Zwietering, and B. H. ter Kuile. 2010. Future challenge to microbial food safety. Int. J. Food Microbiol. 139:S79-S94.

15. Huss, H. H., A. Reilly, and P. Karim Ben Embarek. 2000. Prevention and control of hazards in seafood. Food Control 11:149-156.

16. Jaffee, S. M., and S. Henson. 2004. Agro-food exports from developing countries: the challenges posed by standards, p. 91-114. In M. A. Aksoy and J. C. Beghin (ed.), Global agricultural trade and developing countries. Oxford University Press, Oxford, UK.

17. Ko, W. H. 2010. Evaluating food safety perceptions and practices for agricultural food handler. Food Control 21:450-455.

18. Lankes, H. P. 2002. Market access for developing countries. Financ Dev. 39:1-15.

19. Le Ry, J. M., O. Barry, and E. Legendre. 2007. Plan de relance de la filière halieutique: rapport de l'expert international court terme, projet appui au secteur privé. BEN/009/004. Available at: http://www. ntiposoft.com/domaine_200/pdf/rapport_intermediaire_relance_fili_ re_halieutique2_sw.pdf. Accessed 16 May 2012.

20. Matches, R. J. 1982. Effects of temperature on the decomposition of pacific coast shrimp (Pandalus jordani). J. Food Sci. 47:1044-1047.

21. Mendes, R., A. Huidobro, and L. E. Caballero. 2002. Indole levels in deep-water pink shrimp (Parapenaeus longirostris) from the Portuguese coast. Effects of temperature abuse. Eur. Food Res. Technol. 214:125-130.

22. Omemu, A. M., and S. T. Aderoju. 2008. Food safety knowledge and practices of street food vendors in the city of Abeokuta, Nigeria. Food Control 19:396-402.

23. Ottesen, G. G. 2006. Do upstream actors in the food chain know endusers' quality perceptions? Findings from the Norwegian salmon farming industry. Supply Chain Manag. 11:456-463.

24. Plahar, W. A., G. A. Nerquaye-Tetteh, and N. T. Annan. 1999. Development of an integrated quality assurance system for the traditional Sardinella sp. and anchovy fish smoking industry in Ghana. Food Control 10:15-25.

25. Seaman, P., and A. Eves. 2010. Perception of hygiene training amongst food handlers, managers and training providers-a qualitative study. Food Control 21:1037-1041.

26. Todd, E. C. D., B. S. Michaels, J. D. Greig, D. Smith, and C. A. Bartleson. 2010. Outbreaks where food workers have been implicated in the spread of foodborne disease. Part 8. Gloves as barriers to prevent contamination of food by workers. J. Food Prot. 73:17621773.

27. Trienekens, J. H., P. M. Wognum, A. J. M. Beulens, and J. G. A. J. van der Vorst. 2012. Transparency in complex dynamic food supply chains. Adv. Eng. Inform. 26:55-65.

28. Unnevehr, L. J. 2000. Food safety issues and fresh food products exports from LDCs. Agric. Econ. 23:231-240.

29. Ziggers, G. W., and J. Trienekens. 1999. Quality assurance in food and agribusiness supply chains: developing successful partnerships. Int. J. Prod. Econ. 60-61:271-279. 